\title{
Food Safety and Hygiene Practice among Hotel in Malaysia: Qualitative Approach
}

\author{
Mohammad Halim Jeinie 1, Mohd Shazali Md. Sharif 2, Mazni Saad 3, Norazmir Md Nor ${ }^{*}$ \\ ${ }^{1}$ Faculty of Health Sciences, Universiti Teknologi MARA, 42300, Puncak Alam, Selangor, Malaysia \\ 2 Faculty of Hotel \&Tourism Management, University Teknologi MARA, 42300, Puncak Alam, Selangor, Malaysia \\ ${ }^{3}$ Faculty of Business, Universiti Selangor, 40000, Shah Alam, Selangor, Malaysia
}

\begin{abstract}
This study examines the effectiveness of food safety and hygiene practice (FSHP) among restaurants in a selected Malaysian hotel and impact of FSHP toward culinary intern. It is essential to examine effectiveness FSHP among the hotel restaurants and its impact on culinary intern towards producing competent food handler. Using qualitative method, five (5) of culinary intern were interviewed. The data were then transcribing and analyzed using Atlas.ti software. Finding of a current study confirming the effectiveness FSHP in a hotel restaurant in Malaysia depends on the type of hotel, star rating, and location.

(C) 2016. The Authors. Published for AMER ABRA by e-International Publishing House, Ltd., UK. This is an open access article under the CC BY-NC-ND license (http://creativecommons.org/licenses/by-nc-nd/4.0/).

Peer-review under responsibility of AMER (Association of Malaysian Environment-Behaviour Researchers), ABRA (Association of Behavioural Researchers on Asians) and CE-Bs (Centre for Environment-Behaviour Studies), Faculty of Architecture, Planning \& Surveying, Universiti Teknologi MARA, Malaysia..
\end{abstract}

Keywords: Food safety; food hygiene practices; culinary; culinary intern

\section{Introduction}

People's travel from place to place to explore culinary experience. According to Chrzan (2007) and Santich (2008), in the last two decades' culinary travel has become a form of tourist that generates the highest level of expenditure. As travel, tourism and hospitality industry group are considering the largest industry in the world (Mudambi, 1999). Markedly, 27.44 million international tourists estimate visited Malaysia in the year 2014, an increase of $6 \%$ compared to the year 2013 (The Star, 2015).

\footnotetext{
${ }^{*}$ Corresponding author. Tel.: +6-03-3258 4510

E-mail address: azmir2790@puncakalam.uitm.edu.my
}

2398-4287 @ 2016. The Authors. Published for AMER ABRA by e-International Publishing House, Ltd., UK. This is an open access article under the CC BY-NC-ND license (http://creativecommons.org/licenses/by-nc-nd/4.0/).

Peer-review under responsibility of AMER (Association of Malaysian Environment-Behaviour Researchers), ABRA (Association of Behavioural Researchers on Asians) and cE-Bs (Centre for Environment-Behaviour Studies), Faculty of Architecture, Planning \& Surveying, Universiti Teknologi MARA, Malaysia

DOI: http://dx.doi.org/10.21834/e-bpj.v1i3.360 
The tourist has arrived for short-term accommodation, typically on daily or weekly basis increase demanding of foods consumption in hotels especially hotels that include foods as complimentary for guest staying in hotels. It is a duty of hotel to keep the hotel guest safe including providing safe foods for returning their investment. Furthermore, food safety and hygiene practice among restaurant operation under hotels in Malaysia up till now is under study.

Keeping FSHP reputation is a recipe for restaurant success. The FSHP procedure in different food establishments needs to be enhanced to reduce foodborne illness associated with food safety and hygiene practices. (Djekic et al., 2014). Analysis of disease worldwide has shown that the majority of epidemics resulting from current practices in food preparation includes in restaurants where is prepared for human consumption (Giritlioglu, Batman, \& Tetik, 2011).

The need for educational initiatives aiming to improve the current food safety awareness of this segment of young consumers is essential, especially given their future roles as caregivers for family members at increased risk (Lazou et al., 2012). Any of food handlers involves with handling food including event catering, and other food services must comply with the high standard of food safety and hygiene practice procedure. FSHP consist specific discipline that describes control, provisioning, and storage in ways that prevent foodborne illness. This specific discipline performs by food handler must be carefully coordinate and implement. Limited research about young adults enrolled in higher education establishments has been published concerning their risk of foodborne illness (Lazou et al., 2012). The need for educational initiatives aiming to improve the current food safety awareness especially for that young culinarian. According to our knowledge, there are no studies on FSHP on hotel restaurant in Malaysia has been done. Therefore, the objective of this study was to investigate current FSHP in hotel restaurant impact culinary intern competent.

\section{Literature Review}

\subsection{Food safety and hygiene practice awareness}

Food and hotel business has grown in the nineteenth century arisen formal and legitimate institutions to teach craft cooking (Müller et al., 2009). Even so these institutions have produced culinary student, it is not uncommon for people or industry itself to complained about incompetent graduates. Giritlioglu et al. (2011) report students had poor knowledge in several regards, and that, on the other hand, they rightly considered the practices of personal hygiene to be important in food production.

The study showed that the Greek university students included in the study have, in general, poor food safety knowledge and frequently engage in unsafe food-handling practices (Lazou et al., 2012). After all, Brooks et al.'s (1995) study supported the findings of Taylor (1988) by providing evidence that internship experience related to the beneficial changes in the student's self-concept. Employers received students with internship experience as being significantly better qualified. In addition to culinary related skills and education, employees require specific life skills to survive or thrive in an increasingly complex environment (Müller et al., 2009).

\subsection{Culinary intern}

Food and hotel business has grown in the nineteenth century arisen formal and legitimate institutions to teach craft cooking (Müller et al., 2009). Even so these institutions have produced culinary student, it is not uncommon for people or industry itself to complained about incompetent graduates. Giritlioglu et al. (2011) report students had poor knowledge in several regards, and that, on the other hand, they rightly considered the practices of personal hygiene to be important in food production. The study showed that the Greek university students included in the study have, in general, poor food safety knowledge and frequently engage in unsafe food-handling practices (Lazou et al., 2012). After all, Brooks et al.'s (1995) study supported the findings of Taylor (1988) by providing evidence that internship experience related to the beneficial changes in the student's self-concept. Employers received students with internship experience as being significantly better qualified. In addition to culinary related skills and education, employees require specific life skills to survive or thrive in an increasingly complex environment (Müller et al., 2009). 
A primary contributing factor to the evolution of culinary art as vocational skill in Malaysia related to the encouraging growth of tourism industries. Ever since 1985 to present, the Malaysian government has made tourism sectors as the 2nd national revenue (Zakaria et al., 2010). There is a high need for food safety education among young adults on topics related to food temperature control, proper food preparation practices, prevention of cross contamination, suitable cleaning and hygiene procedures, high-risk groups, and other contributing factors to foodborne diseases and prevention strategies. To produce competent future food handler, student need to have FSHP foundation in themselves as a platform there to growth their professional career as well to create free hazards workplace.

\section{Methodology}

\subsection{Research Design}

The qualitative approach was employed using a semi-structured interview with the relevant authorities that closely involved with endorsement FSHP. To assess the level of food hygiene and safety, the unit analysis of this research was at the individual level. The targeted population was a culinary student that already complete two subjects under the code subject to HTC297 (industry training) and HTC652 (industry training). The tools used to gather information for the objective of this study were through interview survey then interoperated and process with Atlas.ti software.

\subsection{Informant profile}

Five informants involved in the interview. The informants selected from Faculty Hotel and Tourism Management, Universiti Teknologi MARA (UiTM), Permatang Pauh, Penang. Informants consist of three (3) male and two (2) women, currently studying program of Culinary Art with 2.5 to 3.8 Cumulative Grade Point Average (CGPA). The informant criteria must complete two (2) industry training with 2 (two) different hotel organization.

Table 1: Informant profile

\begin{tabular}{llcc}
\hline Informant & Sex & CGPA & Place of internship \\
\hline Informant 1 & Male & 3.78 & $\begin{array}{l}\text { 1. Island } \\
\text { 2. Urban }\end{array}$ \\
\hline Informant 2 & Male & 3.33 & $\begin{array}{l}\text { 1. Urban } \\
\text { 2. Suburban }\end{array}$ \\
& & & $\begin{array}{l}\text { 1. Suburban } \\
\text { 2. Suburban }\end{array}$ \\
\hline Informant 3 & Male & 2.58 & $\begin{array}{l}\text { 1. Island } \\
\text { 2. Urban }\end{array}$ \\
\hline Informant 4 & Female & 2.98 & 1. Urban \\
& & & 2. Suburban \\
\hline Informant 5 & Female & 3.22 &
\end{tabular}

\section{Qualitative finding}

The informants were asked 'Can you describe food safety and hygiene practice during industry internship?' during the interview session. Finding showed FSHP to be classified into three categories: type of hotel, hotel star rating and location of the hotel. 


\subsection{Type of hotel}

Type of hotel can be classified according to markets they attempt to attract their guest. In this study, the type of hotel was divided into three main categories which are (1) city hotel, (2) resort and (3) others hotel according to the feedback from an informant. FSHP implementation in hotels restaurant may be slightly different based on the type of hotel.

Table 2: Informant Feedback

\begin{tabular}{l|l}
\hline \multicolumn{1}{l}{ Answer } \\
\hline Informant 2 & $\begin{array}{l}\text { "...FSHP implantation in the resort is much tougher rather than city hotel ...during an internship in } \\
\text { the resort, every single day my immediate supervisor has a regular check on my entire uniform up } \\
\text { from kitchen hat to safety boots rather than city hotel... city hotel too busy with daily routine but my } \\
\text { immediate supervisor would comment on my entire if I missed something..." } \\
\text { "... on the first day of internship in resort my chef asks me to perform the correct procedure to wash } \\
\text { hand, and it continues until several weeks then, it's become a routine for me to wash hand } \\
\text { according to right procedure... meanwhile, in a city hotel, it's totally different from the resort, } \\
\text { supervisor a bit lack of monitoring me even though we a busy with daily production. I had to follow } \\
\text { several procedures to avoid any contamination from any food contact... either in city hotel or resort } \\
\text { we had to monitor chiller and freezer temperature while starting shift and end shift... sometimes I } \\
\text { had to help to clean the chiller and freezer base on scheduled make by sous chef ..." }\end{array}$ \\
\hline $\begin{array}{l}\text { "...for me the implementation of FSHP in both boutique hotel and resort is almost same, and the } \\
\text { implementation is very strict...I had to follow lots of hygiene procedure in daily routine, regular check } \\
\text { for temperature on chiller and freezer at my workstation... it is my duty to keep our work station } \\
\text { clean, and organized as chef wanted..." }\end{array}$ \\
\hline
\end{tabular}

\subsection{Hotel star rating}

Hotels strategy on attracting guest will always provide the best service which they can offer. Indeed, star-rating of hotels will influence working culture in the organization. Therefore, in this study has touch issue on how star-rating of hotel influence of FSHP implication.

Table 3: Informant Feedback

\begin{tabular}{l|l}
\hline \multicolumn{1}{l}{ Answer } \\
\hline Informant 1 & $\begin{array}{l}\text { "....at the first week of an internship in the resort the chef won't let me cook, the chef assigns me a } \\
\text { steward to show me how the detail on cleaning every part of kitchen... the steward stress me that it } \\
\text { is important to maintain the kitchen clean because this is the heart of hotels and reputation of hotel } \\
\text { begin from here (kitchen)..." }\end{array}$ \\
\hline $\begin{array}{l}\text { "...my comment on 3-star hotel on the implication of FSHP is in minimum...from my experience on } \\
\text { 3-star hotel the head chef a more focus on production output rather than cleanliness... sometimes } \\
\text { during peak time the chef doesn't care the floor is wet sometimes it's slippery, and the workstation is } \\
\text { not in pleasant condition but after the peak time over then clean work begun..." }\end{array}$ \\
$\begin{array}{l}\text { "... even the boutique hotel which entitles of 3-star hotel, from my observation the kitchen crew very } \\
\text { good attitude in maintaining personal hygiene.... they have set some rules in the kitchen which } \\
\text { whoever wanted to go for smoking, they have to remove uniform, chef hat, and apron and even } \\
\text { going to toilet we have to remove apron...meanwhile for a 5-star hotel it even stricter compare my } \\
\text { experience in boutique hotel... I think because of the reputation they wanted us to be more caution } \\
\text { especially related the safety of food that we produced." }\end{array}$ \\
\hline
\end{tabular}

\subsection{Location of hotel}

A hotel is a focal point which guest emanates for socializing. Indeed, almost all kind of hotels offers a place to conduct meetings or banquet halls for any function. This sort of function depends on location choose from organizer 
some may prefer in urban, suburban or on islands. Every form of function required food to serve. The demand for food requires special attention for kitchen department implantation of FSPH due of accessibility of raw ingredient either perishable or non-perishable. Due of that situation, based on informant experience they did give feedback on FSHP implication on location will affect the implication.

Table 4: Informant Feedback

\begin{tabular}{|c|c|}
\hline & Answer \\
\hline Informant 1 & $\begin{array}{l}\text { "... Industry training in Langkawi provide me very good experience in FSHP, imagine that it takes } \\
\text { few days to order fresh vegetable from the mainland in rainy session... raw materials that come } \\
\text { from mainland takes several days to arrive... each item arrive must carefully handle and stored } \\
\text { well... Therefore, FSHP is very important for everyone who handles the inventory to ensure the } \\
\text { material can last for a long time... }\end{array}$ \\
\hline Informant 3 & $\begin{array}{l}\text { "...school holiday is the busiest day for kitchen crew, especially in banquet kitchen... during this time } \\
\text { purchasing and receiving happen daily and usually during morning shift I have to perform cleaning } \\
\text { and washing for a perishable item before transfer to storing area... during evening shift on every } \\
\text { Monday and Thursday, the chef will do cleaning on walking chiller and walking freezer, and it's a } \\
\text { duty for me to help them... while cleaning every cuts vegetable which a not uses more than three } \\
\text { days will be transferred to the cafeteria, and any rotten vegetable will be throw away..." }\end{array}$ \\
\hline Informant 5 & $\begin{array}{l}\text { ".... city hotel and the suburban hotel has different similar guest profile either guest register as a } \\
\text { tourist or for business purpose... they consider hotel guest our task, therefore, to make sure the } \\
\text { food is safe to consume..." }\end{array}$ \\
\hline
\end{tabular}

\section{Discussion}

In this study, the informants have very positive feedback on implication FSHP in the hotel restaurant. Surprising, all informant review indicated hotel restaurants have the taking part to ensure food produce is safe to consume. The result shows star-rating of the hotel have an effect on implication effectiveness FSHP. In spite of one informant has a comment on 3-star hotel which has the minimum implication of FSHP in their premises, they urge to continue to deliver safe food. According to Harrington, Ottenbacher, \& Kendall, 2011, food safety is very important for restaurant consumers, as these perceptions may result in the loss of customers if they decide to dine at other restaurants that are considered safer.

Consumer perception of food safety is particularly important for restaurant manager and owners as these perceptions may result in the loss of client to eat at "safer" restaurants. Therefore, this study has revealed positive implication of FSHP among restaurant hotels in Malaysia and indirectly benefit culinary intern on doing their industry internship as a learning process. Providing safe food and enhancing customer satisfaction are widely recognized as important factors leading to the success of companies in the food service industries (Sim, Mak, \& Jones, 2006).

In another hand, this study reveals the type of hotel either it was a business hotel, resort or a boutique hotel has their procedure implementing FSPH in their premises. Meanwhile, the location of the hotel has no significant result toward implementation FSPH. Hotel type is an important strategic variable that related to hotel service, facilities, operation, and target market segments, which result in different hotel performance levels. Therefore, future culinary intern wishes to proceed their industry internship should consider the type of hotel to proceed their industry training due type of hotel will result in a different experience. According to Cullent (2010) experiential learning experienced by the student studying culinary arts, which places the students' educational, interpersonal and social development at the center of the learning process. Therefore, it is essential for the future student of culinary art to choose the right hotel to proceed professional career, and places of practical training duty are to deliver the right knowledge, sufficient skills and positive attitude toward their apprentice.

\section{Conclusion}

In conclusion, FSHP among three to five-star hotel restaurants in Malaysia providing safe food which they can offer. The incident related to risk towards foodborne illness in restaurant operates under hotels at Malaysia is at minimum levels. Implementation of FSHP in hotel restaurants has success to minimize foodborne disease, but the 
incident might be happening due to human errors. This study is to recognize dependability on industry training in a hotel in Malaysia providing significance knowledge, attitude and practice of FSHP toward culinary intern. Indeed, the industry internship is impotent to produce competent future food handler as pursue a professional career. The people working in the kitchen had played important roles to develop competent future food handler by providing real simulations working environment.

\section{Acknowledgements}

This research was funded by Mybrain15 under Ministry of Education Malaysia through the Faculty of Health Sciences, Universiti Teknologi MARA.

\section{References}

Arendt, S. W., Paez, P., \& Strohbehn, C. (2013). Food safety practices and managers; perceptions: a qualitative study in hospitality. International Journal of Contemporary Hospitality Management, 25(1), 124-139.

Brooks, L., Cornelius, A., Greenfield, E., \& Joseph, R. (1995). The relation of career related work or internship experiences to the career development of college seniors. Journal of Vocational Behavior, 46(3), 332-349.

Cullen, F. (2010). Phenomenological Views and Analysis of Culinary Arts Student Attitudes to National and International Internships: The "Nature of Being" Before, During, and After International Internship. Journal of Culinary Science \& Technology, 8(2-3), 87-105

Chrzan, J. (2007) Dreaming of Tuscany: The anthropology of culinary tourism. Expedition, 49(2), 21- 27

Djekic, I., Smigic, N., Kalogianni, E. P., Rocha, A., Zamioudi, L., \& Pacheco, R. (2014). Food hygiene practices in different food establishments. Food Control, 39, 34-40.

Giritlioglu, I., Batman, O., \& Tetik, N. (2011). The knowledge and practice of food safety and hygiene of cookery students in Turkey. Food Control, 22(6), 838-842.

Harrington, R. J., Ottenbacher, M. C., \& Kendall, K. W. (2011). Fine-Dining Restaurant Selection: Direct and Moderating Effects of Customer Attributes. Journal of Foodservice Business Research, 14(February 2013),

Knutson, B. (2000). College students and fast food: How students perceive restaurant brands. Cornell Hospitality Quarterly, 41(3), 68-74.

Lazou, T., Georgiadis, M., Pentieva, K., McKevitt, A., \& lossifidou, E. (2012). Food safety knowledge and food-handling practices of Greek university students: A questionnaire-based survey. Food Control, 28(2), 400-411.

Mudambi, R. and Baum, Thomas. (1999) Economic and management Methods for Tourism and Hospitality Research: Quantitative Method, The Introductory Note, John Wiley \& Son, New York.

Müller, K. F., Vanleeuwen, D., Mandabach, K., Harrington, R. J., \& Mu, K. F. (2009). The effectiveness of culinary curricula : a case study.

Santich, B. (2008) Gastronomy and Gastronomic Tourism, 1st Gastronomic Conference, KDU College, Petaling Jaya, Kuala Lumpur.

Sim, J., Mak, B., \& Jones, D. (2006). A Model of Customer Satisfaction and Retention for Hotels. Journal of Quality Assurance in Hospitality \& Tourism, 7(3), 1-23

Taylor, M. S. (1988). Effects of college internships on individual participants. Journal of Applied Psychology, 73(3), 393-401.

Zakaria, M. A., Hamed, S., Wahab, A., \& Jasmi, M. A. (2010). Culinary Art Education: A Demanding Profession In Culinary Tourism for Malaysian 's New Economy Niche, (November), 10-11. 